\title{
Többcsatornás mikrofluidikai rendszerek fejlesztése kromatográfiás alkalmazásokhoz
}

\author{
NAGY Andrea* \\ Debreceni Egyetem, Szervetlen és Analitikai Kémia Tanszék, Egyetem tér 1., 4032 Debrecen, Magyarország
}

\section{Bevezetés}

A mikrofluidika az analitikai kémia egyik, jelenleg intenzíven kutatott területe, amely nano- és pikoliternyi térfogatú folyadékok áramoltatására, elemzésére alkalmas eszközök tervezésével, előállításával, tanulmányozásával foglalkozik. ${ }^{1,2}$ A kutatások célja, hogy mikro- és nanofabrikációs eljárások segítségével a számítógép csipek méretével összevethetö nagyságú, integrált laboratóriumokat (lab-on-a-chip) tervezzenek és készítsenek, ezáltal csökkentsék a felhasznált minta- és reagensmennyiséget, az elemzések költségeit és legföként az analízisek időtartamát. ${ }^{3-5}$

A mikrofluidikai csipek analitikai alkalmazásának számos előnye ismeretes, mégis viszonylag kevés mikrocsip alapú kromatográfiás rendszert fejlesztettek $\mathrm{ki}^{6}{ }^{6}$ ennek okai a kromatográfiás töltetek kialakításának nehézségeiben keresendőek. $^{7}$ Több olyan rendszer ismert, ahol a kromatográfiás töltetek mikrocsipbe integrálásához valamilyen fritet helyeztek a csatornába, ezzel visszatartva a részecskéket. ${ }^{8,9} \mathrm{~A}$ fritekkel való nehézségek miatt viszont több kutatócsoport is olyan módszereket fejlesztett, amelyek segítségével a kromatográfiás töltetek frit nélkül hozhatóak létre (például többrétegű mikrofluidikai csipek használatával, ${ }^{10,11}$ monolitok $^{12}$ vagy akár ideiglenes szükületek ${ }^{13,14}$ csatornákban történő kialakításával).

Munkánk során kromatográfiás elválasztási technikák miniatürizálását, kromatográfiás töltetek mikrofluidikai csipben való kialakítását és alkalmazását tüztük ki célul. Ehhez reprodukálható, gyors töltési módszert fejlesztettünk ki. További célunk volt olyan többcsatornás mikrofluidikai rendszerek kifejlesztése, amelyek párhuzamos csatornáiban több, akár különböző kromatográfiás töltet kialakítására van lehetőség, amelyeken egyidejüleg végezhetünk párhuzamos elválasztásokat. A mikrofluidikai rendszerek jelenlegi alkalmazásának egyik hátránya a rendszerekhez kapcsolt érzékeny detektálási módszerek hiánya. Az általunk kifejlesztett mikrocsipekhez megvizsgáltuk az atomspektoszkópiás detektorok alkalmazhatóságát.

\section{Kutatási eredmények}

\subsection{Kromatográfiás töltetek kialakítása a csatornákban}

Kromatográfiás részecskék poli(dimetil-sziloxán)-ból (PDMS) készített mikrofluidikai csip csatornájában történő visszatartására kezdetben egy átmeneti csatornaszükületet hoztak létre, a mikrocsip felületére merölegesen alkalmazott nyomóerővel. ${ }^{13,14}$ Az ilyen módon kialakított szilika aerogél töltetek azonban instabilak voltak, használat során degradálódtak vagy részlegesen kimosódtak.

Éppen ezért állandó szükületet alakítottunk ki a csatornákban, elöször a csatornamagasság megfelelő mértékű csökkentésével (az öntőforma síkjából kiemelkedő csatornamintázat megfelelő helyen történő megkarcolásával létrehozott fritszerü réteg segítségével ${ }^{15}$ ), majd a csatornák szélességének egy adott ponton történő csökkentésével.

A szükületek kialakításának legegyszerübb és leginkább reprodukálható módjának a mintázatok tervezése során történő megrajzolását találtuk. A kb. 10-20 $\mu \mathrm{m}$ széles és $50 \mu \mathrm{m}$ hosszú csatornákat a $100 \mu \mathrm{m}$ széles csatornákba rajzoltuk, ezután a kinyomtatott litográfiás maszkot felhasználva készítettük el az öntőformát, majd a mikrocsipeket. A töltési folyamat során az első részecskék a méretüknél legfeljebb háromszor nagyobb átmérőjü szükületek elején megragadva tartják vissza a mögöttük jövő részecskéket (zárókőhatás). ${ }^{13}$

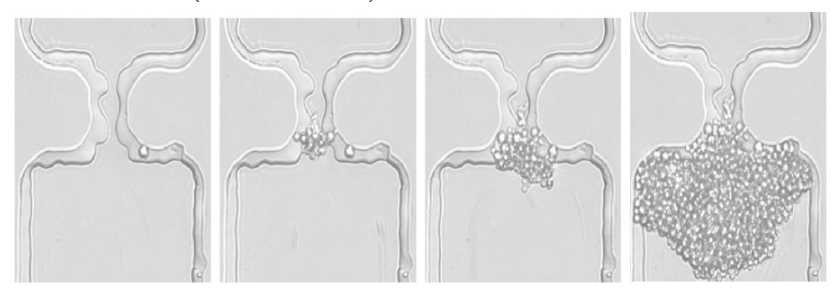

1. Ábra. A kromatográfiás töltetek kialakításának folyamata, a zárókőhatás (10 $\mu \mathrm{m}$-es $\mathrm{C} 18$-as kromatográfiás részecskék, $100 \mu \mathrm{m}$ csatornaátmérö).

\subsection{Többcsatornás mikrofluidikai rendszerek}

Három különböző kromatográfiás töltet kialakítására alkalmas csatornarendszereket terveztünk, ahol a csatornák egymástól függetlenek (2.a és 2.b ábra) így a kromatográfiás részecskék egymás után juttathatóak be a párhuzamos csatornákba, illetve olyan rendszereket is, ahol a kromatográfiás részecskék bejuttatására szolgáló csatornarészek egymással kapcsolatban állnak, közös portban végződnek (2.c és 2.d ábra), így az azonos kromatográfiás töltetek egyidejüleg alakíthatóak ki a rendszerekben. Mindkét típusú mintázatnál terveztünk olyan változatot, ahol három eltérő minta három különböző kereszteződésen juttatható a szeparációs csatornákba (2.a és 2.c ábra), illetve olyat is, ahol a bejuttatott egyetlen minta egyenletesen oszlik el a párhuzamos csatornák között (2.b és 2.d ábra). 

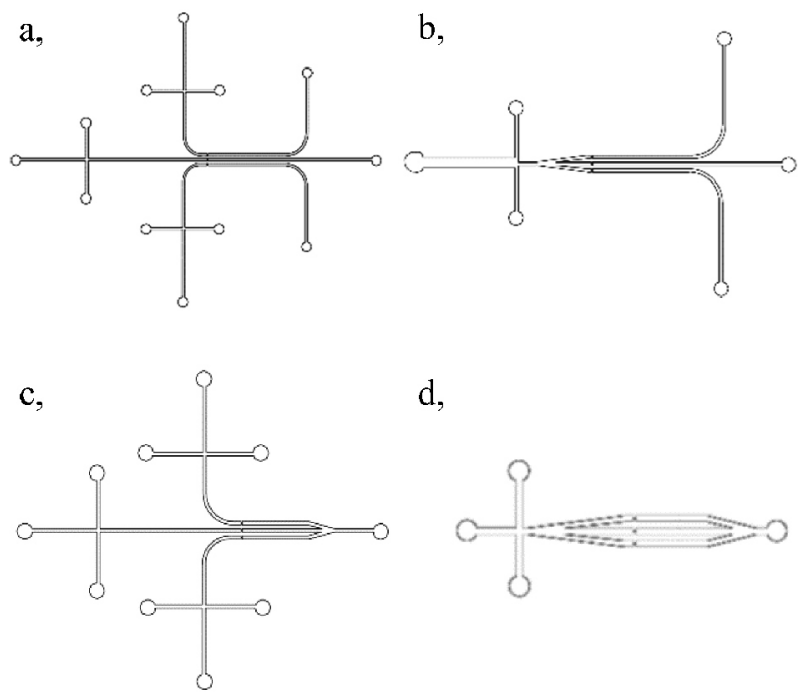

d,

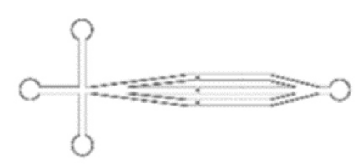

2. Ábra. Háromcsatornás mikrofluidikai rendszerek AutoCAD programmal készített rajzai.

A többcsatornás rendszerek egyik nagy előnye az egyidejűleg végezhető, párhuzamos elválasztások lehetősége. Az egymástól független rendszerekben három különböző kromatográfiás töltetet ( $5 \mu$ m-es RP-1, C8 és C18 szénhidrogénlánccal módosított szilikagél részecskékből) alakítottunk ki. Ezekre zöld ételfesték keveréket injektáltunk (sárga (E102, tartrazin) és kék (E133, Brillantkék FCF) komponensekből), ami közel azonos mennyiségben oszlott el a csatornák között (3.a ábra). A kék festék retenciója az RP-1-es tölteten volt a legerősebb, 25\% metanol-víz mozgófázis alkalmazása mellett a leggyorsabban elérhető teljes elválasztást a C8-as szénhidrogénlánccal módosított szilikagél részecskékből készült tölteten kaptuk (3.b ábra).

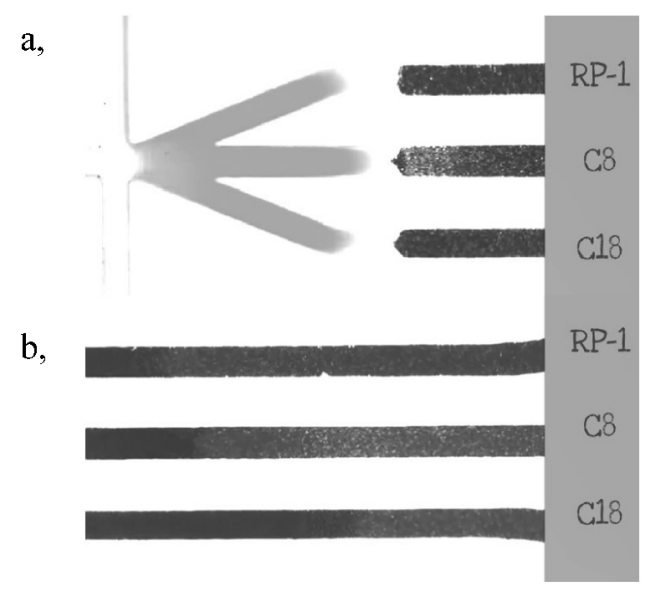

3. Ábra. Zöld ételfesték keverék egyidejű elválasztása három különböző (RP-1, C8, C18) kromatográfiás tölteten $100 \mu \mathrm{m}$ széles csatornákban.

Olyan tíz párhuzamos csatornát tartalmazó mikrocsipet terveztünk, ahol azonos kromatográfiás tölteteket kialakítására van lehetőségünk, viszont a mintát a töltetekre egymástól függetlenül injektálhatjuk (4.a ábra), tehát egyidejüleg akár tíz párhuzamos elemzés is elvégezhető tíz

különböző mintából. A tizenkét párhuzamos csatornát tartalmazó mikrocsip mintázata is azonos kromatográfiás töltetek kialakítására ad lehetőséget, de itt az injektált minta tizenkét részre oszlik, így ugyanazon mintából végezhető tizenkét párhuzamos mérés egyidejüleg (4.b ábra). Ezen párhuzamos csatornák száma növelhető akár 60 -ig is (4.c ábra), míg a további csatornarészek megfelelő elhelyezésére lehetőség van (például a portok és az injektáló egységek megfelelö távolságban kell legyenek egymástól).

a,

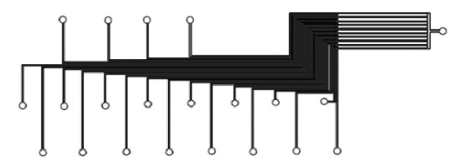

b,
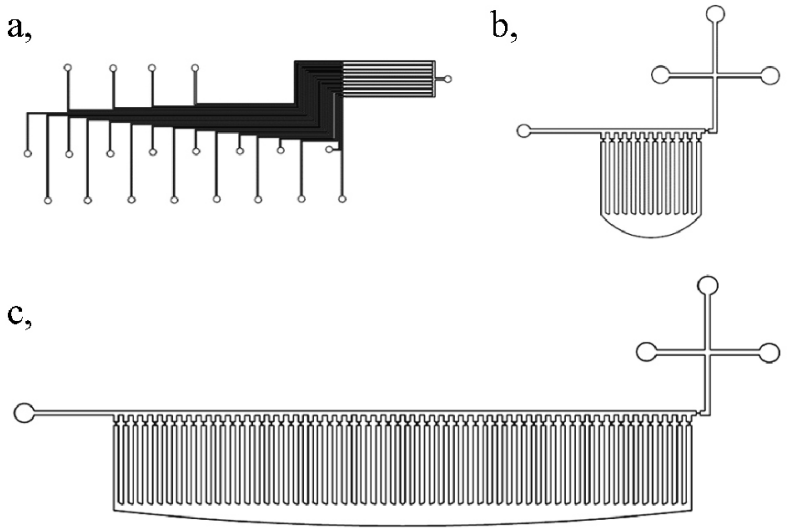

4. Ábra. Tíz (a,), tizenkettő (b,) és 60 párhuzamos csatornát tartalmazó mintázatok AutoCAD programmal készített rajzai.

A sokcsatornás rendszerekben is a párhuzamos csatornák tervezése során létrehozott szükületek segítségével tartottunk vissza kromatográfiás részecskéket. A közös kivezető porton keresztül bejuttatott kromatográfiás részecskék eloszlottak a csatornák között és gyorsan tömör töltetek keletkeztek.

A párhuzamos kromatográfiás tölteteken való elválasztások demonstrálására sárga és kék ételfesték keverékének mindössze $1 \mu$ l-ét injektáltuk a rendszerbe, amely egyenlően oszlott el a tizenkét párhuzamos kromatográfiás töltet között (5.a ábra). A keverék sárga komponense visszatartás nélkül haladt át a C18-as szénhidrogénlánccal módosított részecskékből álló tölteteken (5.b ábra), a megkötődött kék komponens metanolos mosással oldottuk le róluk (5.c ábra). Az elválasztásához mindössze 30 másodpercre volt szükség.

Az elválasztott komponensek detektálása a tizenkét csatornában a színintenzitás változásának egyidejü mérésével történt (5.d ábra). A $2 \mathrm{~mm}$ hosszúságú töltetre vonatkozó elméleti tányérmagasság értéke $0,75 \mu \mathrm{m}$-nek adódott $(0,0176 \mathrm{~mm} / \mathrm{s}$, vagyis $4,2 \mathrm{nl} /$ perc áramlási sebesség esetén), az elméleti tányérszám 2500 (1 330 000/m) volt. A Brillantkék FCF (E133) festékre meghatározott teljes kapacitásra ugyanezen a tölteten $7,5 \cdot 10^{-12} \mathrm{~mol} / \mu \mathrm{m}$ értéket kaptunk. A párhuzamos csatornákban az áramlási sebességek nem azonosak, ezeket a különböző áramlási sebességeket felhasználva egyetlen mérés alapján megalkotható a van Deemter diagram. A diagram görbéjének minimumát meghatározva a hatékony kromatográfiás elválasztáshoz szükséges optimális áramlási sebesség egyszerüen meghatározható (5.e ábra), esetünkben ez 4,2 nl/perc-nek $(0,0176 \mathrm{~mm} / \mathrm{s})$ adódott. ${ }^{16}$ 


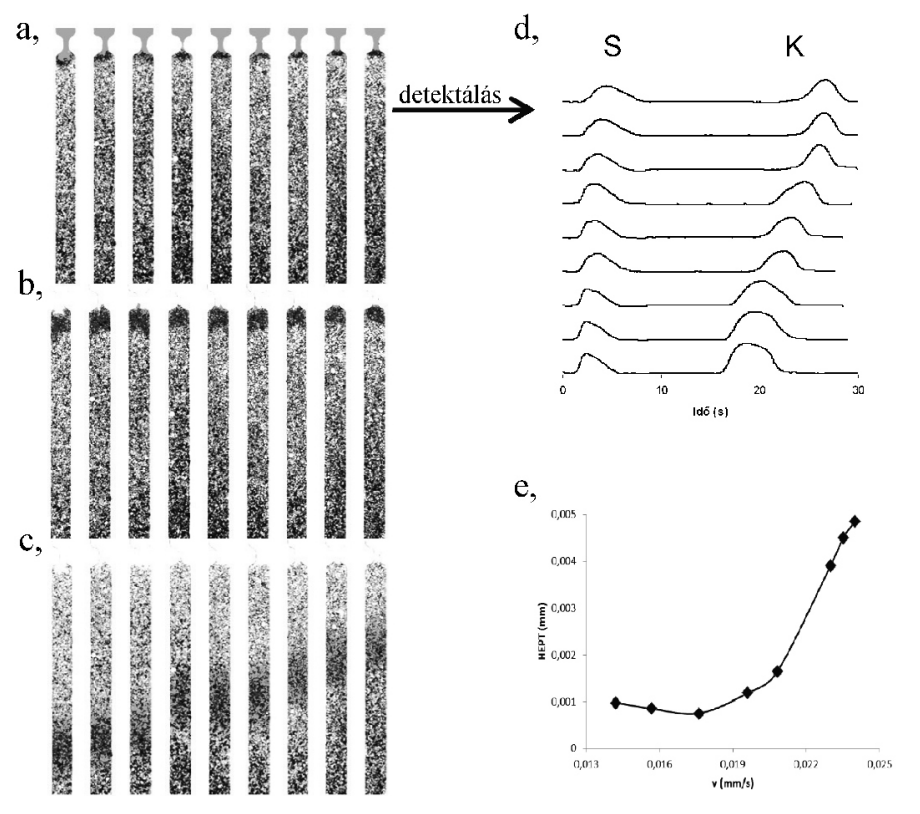

5. Ábra. Zöld ételfesték keverék egyidejü elválasztása tizenkét párhuzamos $100 \mu \mathrm{m}$ széles kromatográfiás tölteten (a-c,), az elválasztások során kapott kromatogramok (d,) és a mért adatokból szerkesztett van Deemter görbe (e,).

A szimulációs szoftverek lehetőséget nyújtanak a mikroszkópikus rendszerek modellezésére és így hatékonyabb tervezésére. A mikrocsipek csatornáiban fellépő áramlási viszonyok szimulálására a COMSOL Multiphysics szoftvert alkalmaztuk, amellyel folyadékok áramoltatását/áramlását tudjuk modellezni mikrofluidikai rendszerekben.

A tizenkét párhuzamos csatornát tartalmazó rendszerben jelentkező sebességkülönbséget szimulációk segítségével is igazoltuk. Vizsgáltuk az áramlási sebességek különbözőségének okait és kísérleteket végeztünk a sebességek párhuzamos csatornákban való kiegyenlítésére. COMSOL szimulációk segítségével új csatornamintázatot fejlesztettünk, a párhuzamos csatornák feletti vízszintes csatorna geometriájának megváltoztatása szinte azonos párhuzamos csatornákbeli sebességeket eredményezett. Kísérletes úton bizonyítottuk, hogy a szimulációs szoftverek segítségével a mikrocsipek tervezése nagymértékben egyszerüsíthető, gyorsítható. ${ }^{17}$

\subsection{Atomspektroszkópiás detektorok kapesolása mikrofluidikai csipekhez}

$\mathrm{Az}$ analitikai rendszerek miniatürizálásának egy kritikus pontja a kis mintamennyiségek kellően érzékeny detektálására képes módszer fejlesztése. Mikrocsipjeinket lángatomabszorpciós készülékekhez, majd lézerindukált plazma spektrométerhez kapcsoltuk.

Megállapítottuk, hogy a 30 ěl az a legkisebb mintatérfogat, ami még az elfogadható érzékenységủ és reprodukálhatóságú FAAS detektáláshoz szükséges, ez azonban még mindig nagyon nagy folyadéktérfogat a tipikus mikrofluidikai alkalmazásokhoz. Az eluált térfogatok növelése érdekében megnöveltük a mikrotölteteink dimenzióit (a kromatográfiás töltetek megnövelt méretei $20 \mathrm{~mm}$ x $1 \mathrm{~mm}$ x 0,1 mm).
Az eluátumokat $\sim 40 \mu \mathrm{l}$ térfogatú, müanyag pipettahegyből készült hidrofób edényekbe gyüjtöttük, amelyeket a csatornák végén kialakított portokhoz csatlakoztattunk (6.a ábra). A lángatomabszorpciós spektrométer porlasztójának teflonkapillárisán keresztül a minta teljes térfogatát $(\sim 30 \mu \mathrm{l})$, pillanatszerüen szippantottuk fel a spektrométer lángjába (diszkrét mikroinjektálás) (6.b ábra).
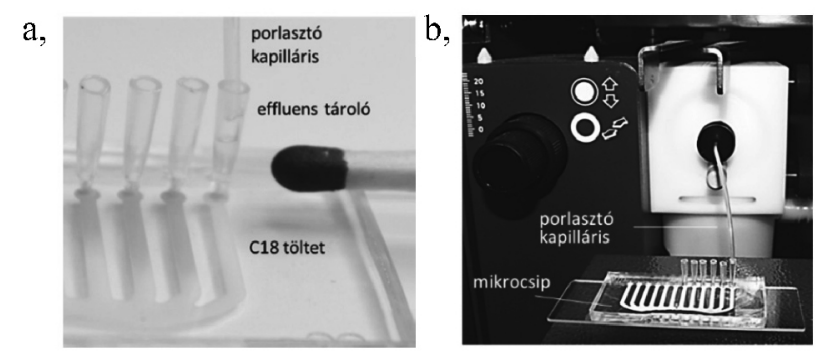

6. Ábra. Fordított fázisú ( $5 \mu \mathrm{m}, \mathrm{C} 18)$ kromatográfiás tölteteken megkötött intenzív sárga színü Cr(VI) minták és a csatornák végéhez csatlakoztatott effluenstároló edények (a,), illetve a mikrocsip és az FAAS készülék összekapcsolása (b,).

A rendszer teszteléséhez ionpár kromatográfiás módszerrel $\mathrm{Cr}(\mathrm{VI})$-ot kötöttünk meg a csatornákban kialakított fordított fázisú tölteteken, majd az eluált komponenseket juttattuk a FAAS készülékbe. Az elválasztás/dúsítás során az irodalomból ismert körülményeket alkalmaztuk. ${ }^{18}$ A mintában lévő $\mathrm{Cr}(\mathrm{III})$ ionok és más ionos komponensek visszatartás nélkül áthaladtak a tölteten, míg a $\mathrm{Cr}(\mathrm{VI})$ ionpárt képezve a tetrabutil-ammónium-ionokkal (TBA) megkötődött a C18-as szénhidrogénlánccal módosított szilikagél részecskék felületén. A megkötődött $\mathrm{Cr}(\mathrm{VI})$ minták metanollal moshatóak le a töltetröl. 
A mikrocsipről készített fénykép szoftveres kiértékelésével (pl. CP Atlas 2.0, vékonyréteg kromatográfiás kiértékelő program $^{19}$ ), azaz a színintenzitások mérésével is kaphatunk információkat a minták Cr(VI) tartalmáról (legalább $20 \mu \mathrm{g} / \mathrm{ml}$ $\mathrm{Cr}(\mathrm{VI})$ tartalom szükséges).

A töltetek (5 $\mu \mathrm{m}, \mathrm{C} 18,20 \mathrm{~mm} \times 1 \mathrm{~mm} \times 0,1 \mathrm{~mm})$ teljes kapacitás értékére $0,45 \mu \mathrm{g} / \mathrm{mm}$-t határoztunk meg. $80 \mu \mathrm{l}$ $\mathrm{Cr}(\mathrm{VI})$ mintaoldat töltetre vitelével és a metanolos $30 \mu \mathrm{l}$ térfogatú effluens FAA spektrométerbe porlasztásával 0,0031 ěg/ml kimutatási határt értünk el. Tizenkét effluens lángatomabszorpciós mérése esetén a csúcsmagasságokra és csúcs alatti területekre számított relatív standard deviációk értéke 3,7 RSD\% és 5,8 RSD\% volt. A lángatomabszorpciós spektrométerrel kapcsolt mikrofluidikai rendszerek egyik legnagyobb előnye, hogy tizenkét kromatográfiás elválasztáshoz/dúsításhoz és FAAS detektáláshoz mindössze 5 percre volt szükség. ${ }^{20}$

Az FAAS készülék mikrofluidikai csipekhez való kapcsolása mellett megvizsgáltuk a lézerindukált plazma spektrométer detektorként való használatát, melynek nagy előnye a mikrocsip és a LIBS készülék közötti kapcsolat kialakításának egyszerüsége. A LIBS mérések során nagyenergiájú lézer sugárral lőttük meg a mikrocsipet. A lézer hatására mikroplazma alakul ki a lövés helyén, amely atomizálja és gerjeszti a jelen lévő anyagokat. Az emittált spektrum felvételével, majd az atomvonalak azonosításával minőségi meghatározást végezhetünk.

A mérésekhez a megnövelt méretü (20 mm x $1 \mathrm{~mm}$ x 0,1 $\mathrm{mm}$ ) csatornákban fordított fázisú kromatográfiás tölteteket ( $5 \mu \mathrm{m}, \mathrm{C} 18)$ alakítottunk ki, a rendszerek tesztelésére a már előzőekben használt, ionpár kromatográfián alapuló módszert használtuk. A megkötött Cr(VI) minták elemzése, lézerrel való meglövése történhetett magán a kromatográfiás tölteten, vagy metanolos elúciót követően a csatorna portja körül beszáradt rétegen. A lézersugár hatására keletkező mikroplazma emissziós spektrumát spektrofotométerrel detektáltuk, a króm jellemző, intenzív vonalait 357,869 nm, 359,349 nm és 360,533 nm hullámhosszaknál figyeltük meg. Krómra nézve 28,9 ng/mm² kimutatási határt (LOD) határoztunk meg a 359,349 nm-es vonalnál.

\section{Mikrofluidikai csipek készítése}

A mikrocsipek készítésekor Whitesides és kutatócsoportja által közölt eljárást ${ }^{21}$ alkalmaztuk. Megterveztük a csatornahálózatokat, ezt követöen elkészítettük az öntőformát, amit a mikrocsipek öntéséhez használtunk fel. A lágy litográfiás módszerekkel készített mikrocsipek anyagaként a PDMS-t használtunk, amely $\left(\mathrm{Si}\left(\mathrm{CH}_{3}\right)_{2} \mathrm{O}\right)$ egységekből álló polimer anyag.

A mikrocsipek tervezéséhez AutoCAD számítógépes szoftvert (AutoCAD 2013, Autodesk Inc., San Rafael, CA, USA) használtunk, mellyel pontosan megtervezhetőek az 50-100 $\mu \mathrm{m}$ átmérójü csatornamintázatok. A megtervezett mintázatokat nagyfelbontású nyomtató (3600 dpi, Képpont Kft., Debrecen) segítségével átlátszó fóliára nyomtatva kaptuk a fotolitográfiás maszkot. Ezt a litográfiás maszkot használtuk a mikrocsipek készítéséhez szükséges öntőformák előállításához.

Az öntőforma hordozójaként szolgáló szilícium lapka felületén $\mathrm{kb}$. $35 \mu \mathrm{m}$ vastagságú réteget hoztunk létre a negatív típusú fényérzékeny anyagból (SU-8 2025), majd a fotolitográfiás maszkon keresztül UV fénnyel (365 nm) sugároztuk be. Az UV fénnyel érintkezett részek (csatornamintázat) előhívást követően is a lapon maradtak.

Az így elkészített öntőformára a monomer és a térhálósító adalék 10:1 arányú keverékét öntöttük, melyet $65^{\circ} \mathrm{C}$-os kemencében térhálósítottunk. A térhálósodást követően méretre vágtuk a mikrocsipeket, majd egy kézi lyukasztó segítségével kialakítottuk a $0,7 \mathrm{~mm}$ átmérőjü portokat, amelyeken keresztül pumpacsövekkel csatlakozhatunk a csatornákhoz.

Utolsó lépésként a csatornamintázatot tartalmazó müanyagot levegő plazmával történő aktiválást követően irreverzibilisen egy üveg tárgylemezhez ragasztottuk.

\section{4. Összefoglalás}

PhD munkám során fö célom kromatográfiás töltetek kialakítására alkalmas többcsatornás mikrofluidikai rendszerek fejlesztése, készítése és tanulmányozása volt.

$\mathrm{Az}$ általunk fejlesztett mikrocsipek párhuzamos csatornáiban 3, 12 vagy akár ennél is több kromatográfiás töltet alakítható ki. Ezeken a tölteteken több, párhuzamos elválasztás végrehajtására van lehetőségünk, mellyel nagymértékben csökkenthető az analitikai vizsgálatokhoz szükséges idő és a meghatározások költsége.

$\mathrm{Az}$ ilyen rendszerekben lehetőségünk van különböző töltetek kialakításával kromatográfiás töltetek gyors összehasonlítására vagy az adott analitikai feladathoz megfelelő töltet kiválasztására, így az új módszerek kifejlesztése lényegesen felgyorsulhat. A kromatográfiás részecskékkel töltött PDMS mikrocsipek gyorsan, viszonylag reprodukálhatóan készíthetőek, előállítási és müködtetési költségeik csekélyek. A mikrofluidikai csipek atomspektroszkópiai módszerekkel való összekapcsolásával új detektálási módszerek lehetőségét mutattuk be.

Mivel a gazdasági fejlődéssel egyre több és minél olcsóbb analitikai meghatározás elvégzésére van szükség a jövőben a mikrofluidikai csipeken történő analitikai elemzések széleskörü elterjedése várható.

\section{Köszönetnyilvánítás}

Ezúton szeretnék köszönetet mondani témavezetőmnek, Dr. Gáspár Attilának a munkám során nyújtott segítségéért. Köszönöm Dr. Lázár Istvánnak az aerogélek elkészítését, Dr. Iván Kristófnak és Leelőssyné Tóth Eszternek a szimulációs számítások kivitelezését, illetve a lézerindukált plazma spektrométerrel történt méréseket Dr. Galbács Gábornak és Metzinger Anikónak. 


\section{Hivatkozások}

1. Whitesides, G. M. Nature 2006, 442, 368-373. https://doi.org/10.1038/nature05058

2. Lee, A. Lab Chip 2013, 13, 1660-1661. https://doi.org/10.1039/c3lc90031b

3. Reyes, D. R.; Iossifidis, D.; Auroux, P-A.; Manz, A. Anal. Chem. 2002, 74, 2623-2636. https://doi.org/10.1021/ac0202435

4. Haeberle, S.; Zengerle, R. Lab Chip 2007, 7, 1094-1110. https://doi.org/10.1039/b706364b

5. Manz, A.; Graber, N.; Widmer, H. M. Sens. Actuators 1990, B1, 244-248. https://doi.org/10.1016/0925-4005(90)80209-I

6. de Mello, A. Lab Chip 2002, 2, 48N-54N. https://doi.org/10.1039/b207266c

7. Kutter, J. P. J. Chromatogr. A 2012, 1221, 72-82. https://doi.org/10.1016/j.chroma.2011.10.044

8. Ocvirk, G.; Verpoorte, E.; Manz, A.; Grasserbauer, M.; Widmer, H. M. Anal. Methods Instrum. 1995, 2, 74-82.

9. Sato, K.; Tokeshi, M.; Odake, T.; Kimura, H.; Ooi, T.; Nakao, M.; Kitamori, T. Anal. Chem. 2000, 72, 1144-1147. https://doi.org/10.1021/ac991151r

10. Huft, J.; Haynes, C. A.; Hansen, C. L. Anal. Chem. 2013, 85, 1797-1802. Https://doi.org/10.1021/ac303153a
11. Huft, J.; Haynes, C. A.; Hansen, C. L. Anal. Chem. 2013, 85, 2999-3005. https://doi.org/10.1021/ac400163u

12. Ericson, C.; Holm, J.; Ericson, T.; Hjertén, S. Anal. Chem. 2000, 72, 81-87. https://doi.org/10.1021/ac990802g

13. Gáspár, A.; Piyasena, M. E.; Gomez, F. A. Anal. Chem. 2007, 79, 7906-7909. https://doi.org/10.1021/ac071106g

14. Gáspár, A.; Hernandez, L.; Stevens, S.; Gomez, F. A. Electrophoresis 2008, 29, 1638-1642. https://doi.org/10.1002/elps.200700489

15. Gáspár, A.; Nagy, A.; Lázár, I. J. Chromatogr. A 2011, 1218, 1011-1015. https://doi.org/10.1016/j.chroma.2010.12.091

16. Nagy, A.; Gáspár, A. J. Chromatogr. A 2013, 1304, 251-256. https://doi.org/10.1016/j.chroma.2013.06.065

17. Nagy, A.; Tóth, L. E.; Iván, K.; Gáspár, A. Microchem. J. 2015, 123, 125-130. https://doi.org/10.1016/j.microc.2015.05.019

18. Posta, J.; Berndt, H.; Luo, S. K.; Schaldach, G. Anal. Chem. 1993, 65, 2590-2595. https://doi.org/10.1021/ac00067a008

19. www.lazarsoftware.com

20. Nagy, A.; Baranyai, E.; Gáspár, A. Microchem. J. 2014, 114, 216-222. https://doi.org/10.1016/j.microc.2014.01.008

21. Duffy, D. C.; McDonald, J. C.; Schueller, O. J. A.; Whitesides, G. M. Anal. Chem. 1998, 70, 4974-4984. https://doi.org/10.1021/ac980656z

\section{Development of multichannel microfluidic systems for chromatographic applications}

M.; Widmer, H. M. Anal. Methods Instrum. 1995, 2, 74-82. In our work multichannel microfluidic systems were developed and studied for chromatographic applications. The microfluidic chips were designed and then prepared from polydimethylsiloxane. We developed a new packing process for the preparation of chromatographic packings, which does not require any frit. During this procedure the particles were permanently retained by a bottleneck in the channels.

This bottleneck was created by the reduction of the channel height. (Decreasing the channel height to $15-20 \mu \mathrm{m}$ was enough for the retainment of the $5 \mu \mathrm{m}$ diameter chromatographic particles.) It was achievable by the tapering of the channel pattern at the proper location. On the other way, the bottlenecks were created by the appropriate reduction of the channel width. It was reduced from $100 \mu \mathrm{m}$ to $15-20 \mu \mathrm{m}$, which allowed the reproducible preparation of chromatographic packings from the $5 \mu \mathrm{m}$ diameter particles. The length of the packings was freely variable from $200 \mu \mathrm{m}$ to more centimeters. Using of this process it was possible to prepare chromatographic packings in multichannel systems. We found that a suitable bottleneck can be created even if the contour of the bottleneck (a $10 \mu \mathrm{m}$ wide and $50 \mu \mathrm{m}$ long channel) was drawn directly onto the photolithographic mask and proper lithographic conditions were applied.

In our microfluidic systems 3-12 parallel chromatographic packings were prepared. The number of these parallel chromatographic packings is ultimately limited by the number and the position of the outlet and injection ports. If the system contains only one injection part the number of the chromatographic packings can be increased even to 60. These multichannel systems can contain independent or merged channels. In the independent channel systems different parallel chromatographic packings can be created, while in the merged channels the packings can be formed at the same time through a common outlet port. In both type of microchips we have the possibility to measure one or more sample at the same time. For the sample injection a multiple cross section was necessary, the injected sample distributed between the channels and only a small part of the liquid flowed to the direction of the packings. In those systems where the parallel channels were packed the injected sample can be split to several equal parts before the packings, because the hydrodynamic resistance of the parallel packings was equal.

We separated two component food dye mixture on chromatographic packings prepared from $5 \mu \mathrm{m}$ diameter particles. The two components could be separated within 30 s. The smallest theoretical plate height was $0.75 \mu \mathrm{m}$, the obtained highest plate number value was $2500(1330000 / \mathrm{m})$. The overall capacity of a packing was calculated to be $7.5 \cdot 10^{-12} \mathrm{~mol} / \mu \mathrm{m}$ for the Brilliant Blue FCF (E133) dye.

Three different types of chromatographic packings (from 5 $\mu \mathrm{m}$ diameter RP-1, C8 and C18 particles) were made in microfluidic systems. Parallel chromatographic separations of food dye mixtures were made in these systems (the mobile phase was $25 \%$ methanol-water mixture). These systems were suitable for the fast comparison of chromatographic packings or the selection of the appropriate chromatographic packing for the analytical problem, thus the development of the new methods can be faster.

Simulation softwares were applied for the modeling of the flows in our multichannel systems. During our experiments we observed that the flow rates in the parallel channels were different $(0.014-0.024 \mathrm{~mm} / \mathrm{s})$, reduced towards the outlet 
ports (the ratio of the maximum and minimum velocity was 2.2). For equalizing of the flow rates in the system we designed a new channel pattern, where this flow rate ratio was reduced for 1.05 . The results of the simulations agreed well with the experimental results.

Interfacing the flame atomic absorption spectrometer (FAAS) with our microfluidic systems containing chromatographic packings were demonstrated. In this work the first step was the increasing of the sample volume with the modification of the microfluidic channels/packings dimensions. The minimal sample volume was $30 \mu \mathrm{L}$, this was enough for the reproducible and sensitive FAAS detection. In the modified channel systems the $5 \mu \mathrm{m} \mathrm{C} 18$ packings were $20 \mathrm{~mm}$ long, $1 \mathrm{~mm}$ wide and $0.1 \mathrm{~mm}$ thick. With the developed method preconcentration and separation of the chromium(VI) were demonstrated. The limit of the detection value for the $\mathrm{Cr}(\mathrm{VI})$ was $0.0031 \mu \mathrm{g} / \mathrm{ml}$ with the injection of $80 \mu \mathrm{L}$ sample into the microchip.

The absorbed $\mathrm{Cr}(\mathrm{VI})$ on the packings were analyzed with laser induced breakdown spectroscopy (LIBS), too. After the elution of the $\mathrm{Cr}(\mathrm{VI})$ to the outlet port of the microchip, the dried sample was determined with the laser beam of the spectrometer. The obtained limit of detection value was 28,9 $\mathrm{ng} / \mathrm{mm}^{2}$ for chromium. The detection of the $\mathrm{Cr}(\mathrm{VI})$ can be directly performed on the chromatographic packings, too.

These PDMS microchips packed with chromatographic particles can be prepared in a fast and reproducible way, the costs of the preparation and operation are inexpensive. With the economic development there will be a high demand for the performance of more and cheaper analytical determinations, the widespread distribution of the microfluidic systems for analytical analysis can be expected. 